\title{
Front Matter: Volume 9537
}

, "Front Matter: Volume 9537," Proc. SPIE 9537, Clinical and Biomedical Spectroscopy and Imaging IV, 953701 (4 August 2015); doi: 10.1117/12.2206138

SPIE. Event: European Conferences on Biomedical Optics, 2015, Munich, Germany 


\title{
Clinical and Biomedical Spectroscopy and Imaging IV
}

\author{
J. Quincy Brown \\ Volker Deckert \\ Editors
}

\author{
22-24 June 2015 \\ Munich, Germany \\ Sponsored by \\ SPIE (United States) \\ The Optical Society (United States) \\ With Support from \\ ThorLabs (United Kingdom) \\ Topcon (Japan) \\ Toptica Photonics AG (Germany) \\ Zeiss (United States) \\ Published by \\ SPIE (United States)
}


The papers included in this volume were part of the technical conference cited on the cover and title page. Papers were selected and subject to review by the editors and conference program committee. Some conference presentations may not be available for publication. The papers published in these proceedings reflect the work and thoughts of the authors and are published herein as submitted. The publisher is not responsible for the validity of the information or for any outcomes resulting from reliance thereon.

Please use the following format to cite material from this book:

Author(s), "Title of Paper," in Clinical and Biomedical Spectroscopy and Imaging IV, edited by J. Quincy Brown, Volker Deckert, Proc. of SPIE-OSA Biomedical Optics Vol. 9537 (SPIE, Bellingham, WA, 2015) Article CID Number.

ISSN: $1605-7422$

ISBN: 9781628417029

Copublished by

SPIE

P.O. Box 10, Bellingham, Washington 98227-0010 USA

Telephone +1 3606763290 (Pacific Time) · Fax +1 3606471445

SPIE.org

and

\section{The Optical Society}

2010 Massachusetts Ave., N.W., Washington, D.C., 20036 USA

Telephone 1 202/223-8130 (Eastern Time) · Fax 1 202/223-1096

http://www.osa.org

Copyright (C) 2015, Society of Photo-Optical Instrumentation Engineers and The Optical Society.

Copying of material in this book for internal or personal use, or for the internal or personal use of specific clients, beyond the fair use provisions granted by the U.S. Copyright Law is authorized by SPIE subject to payment of copying fees. The Transactional Reporting Service base fee for this volume is $\$ 18.00$ per article (or portion thereof), which should be paid directly to the Copyright Clearance Center (CCC), 222 Rosewood Drive, Danvers, MA 01923. Payment may also be made electronically through CCC Online at copyright.com. Other copying for republication, resale, advertising or promotion, or any form of systematic or multiple reproduction of any material in this book is prohibited except with permission in writing from the publisher. The CCC fee code is $1605-7422 / 15 / \$ 18.00$.

Printed in the United States of America.

Publication of record for individual papers is online in the SPIE Digital Library.

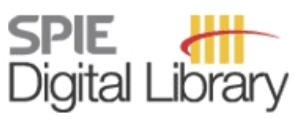

SPIEDigitalLibrary.org

Paper Numbering: Proceedings of SPIE follow an e-First publication model, with papers published first online and then in print. Papers are published as they are submitted and meet publication criteria. A unique citation identifier (CID) number is assigned to each article at the time of the first publication. Utilization of CIDs allows articles to be fully citable as soon as they are published online, and connects the same identifier to all online, print, and electronic versions of the publication. SPIE uses a six-digit CID article numbering system in which:

- The first four digits correspond to the SPIE volume number.

- The last two digits indicate publication order within the volume using a Base 36 numbering

system employing both numerals and letters. These two-number sets start with 00, 01, 02, 03 ,

$04,05,06,07,08,09,0 A, 0 B \ldots$. 0Z, followed by 10-1Z, 20-2Z, etc.

The CID Number appears on each page of the manuscript. The complete citation is used on the first page, and an abbreviated version on subsequent pages. 


\title{
Contents
}

\author{
vii Authors \\ xi Conference Committee \\ xiii Introduction
}

\section{SESSION 1 BIOSPECTROSCOPY AND POC DIAGNOSTICS}

953703 Time-resolved study of microorganisms by Raman spectroscopy [9537-2]

953705 Raman and fluorescence microscopy to study the internalization and dissolution of photosensitizer nanoparticles into living cells [9537-4]

953706 Rapid screening test for porphyria diagnosis using fluorescence spectroscopy [9537-5]

\section{SESSION 2 CLINICAL AND PRECLINICAL DIAGNOSTICS I}

953709 Development of a time-gated fluorescence lifetime microscope for in vivo corneal metabolic imaging [9537-8]

9537 OA Rapid diagnostic imaging and pathologic evaluation of whole core biopsies at the pointof-care using structured illumination microscopy [9537-9]

SESSION 3 CLINICAL AND PRECLINICAL DIAGNOSTICS II

9537 OC Detection of hypercholesterolemia using hyperspectral imaging of human skin (Invited Paper) [9537-12]

9537 OE Accessing deep optical properties of skin using diffuse reflectance spectroscopy [9537-14]

9537 OF Multidimensional spectroscopic data fusion improves precancerous tissue discrimination based on spatially resolved autofluorescence and diffuse reflectance spectroscopy [9537-15]

\section{SESSION 4 CLINICAL AND PRECLINICAL TISSUE CHARACTERIZATION I}

9537 Ol Tissue classification and diagnostics using a fiber probe for combined Raman and fluorescence spectroscopy (Invited Paper) [9537-18]

9537 0J Early diagnosis of tongue malignancy using laser induced fluorescence spectroscopy technique [9537-19] 
9537 OK A topical fluorescent analogue for virtual hematoxylin and eosin histology in point-of-care ex vivo microscopy [9537-20]

9537 OL Autofluorescence spectroscopy for multimodal tissues characterization in colitisassociated cancer murine model [9537-21]

9537 OM Influence of structural length-scale variations on azimuth-resolved light scattering patterns of inhomogeneous cell models [9537-22]

\section{SESSION 5 CLINICAL AND PRECLINICAL TISSUE CHARACTERIZATION II}

9537 OP Video-rate structured illumination microscopy (VR-SIM) for rapid assessment of fresh surgical margins [9537-25]

9537 OR Comparison of the simplified laterally uniform and geometrically realistic optical fiber probe-tissue interface in terms of Monte Carlo simulated diffuse reflectance [9537-27]

9537 OS Fiber-optic technologies for advanced thermo-therapy applied ex vivo to liver tumors [9537-28]

\section{SESSION $6 \quad$ MINIMALLY INVASIVE DIAGNOSTICS / LABORATORY MEDICINE I}

9537 OX Raman spectroscopy of stored red blood cells: evaluating clinically relevant biochemical markers in donated blood [9537-33]

9537 OZ Detection of propofol concentrations in blood by Raman spectroscopy [9537-35]

\section{SESSION $7 \quad$ MINIMALLY INVASIVE DIAGNOSTICS / LABORATORY MEDICINE II}

953710 Registration of intracellular pH in cancer cells with genetically encoded ratiometric sensor (Invited Paper) [9537-36]

953711 Aqueous glucose measurement using differential absorption-based frequency domain optical coherence tomography at wavelengths of $1310 \mathrm{~nm}$ and $1625 \mathrm{~nm}$ [9537-37]

953712 Towards real-time medical diagnostics using hyperspectral imaging technology [9537-38]

953713 Mid-infrared spectroscopic characterisation of an ultra-broadband tunable EC-QCL system intended for biomedical applications [9537-39]

953714 Spectroscopic imaging of blood vessels only near the skin surface for non-invasive blood glucose measurement [9537-40] 
953715 In-situ monitoring of blood glucose level for dialysis machine by AAA-battery-size ATR Fourier spectroscopy [9537-41]

SESSION $8 \quad$ NOVEL TECHNIQUES IN DIAGNOSIS, THERAPY, AND MONITORING

953716 3D imaging of apoptosis by FRET, light sheet fluorescence and scattering microsopy (Invited Paper) [9537-42]

953717 Imaging the spectral reflectance properties of bipolar radiofrequency-fused bowel tissue [9537-43]

953718 Angular and spectrally resolved investigations of yeast cells by light scattering microscopy and goniometric measurements [9537-44]

9537 1B Gold nanorods as photothermal agents and autofluorescence enhancer to track cell death during plasmonic photothermal therapy [9537-47]

\section{ECBO POST-DEADLINE SESSION}

9537 1C Quantitative evaluation of lipid concentration in atherosclerotic plaque phantom by nearinfrared multispectral angioscope at wavelengths around $1200 \mathrm{~nm}$ [9537-83]

POSTER SESSION

9537 IE Detection of early caries by laser-induced breakdown spectroscopy [9537-49]

9537 IF Ultra-sensitive detection of biomarker using localized surface plasmon resonance (LSPR) enhanced by ELISA [9537-50]

$95371 \mathrm{H} \quad$ Wet chemical synthesis of quantum dots for medical applications [9537-52]

9537 1 J Two dimensional spectral camera development for cartilage monitoring [9537-55]

9537 iN Combined analysis of whole human blood parameters by Raman spectroscopy and spectral-domain low-coherence interferometry [9537-60]

953710 Contrast enhancement based on entropy and reflectance analysis for surgical lighting [9537-61]

9537 IP Luminescence monitoring of particle delivery into rat skin in vivo [9537-62]

$95371 Q$ Development of a movable diffuse reflectance spectroscopy system for clinical study of esophageal precancer [9537-63] 
9537 IR Fluorescence ratiometric classifier for the detection of skin pathologies [9537-64]

9537 1T Evaluation of spatially resolved diffuse reflectance imaging for subsurface pattern visualization towards applicability for fiber optic lensless imaging setup: phantom experiments and simulation [9537-66]

953720 Spectral fiber sensors for cancer diagnostics in vitro [9537-73]

953722 Reproducible high-resolution multispectral image acquisition in dermatology [9537-76]

953724 Temperature dependence of the fluorescence spectrum of ZnCdS nanoparticles introduced into adipose tissue in vitro [9537-78]

953726 Hyperspectral imaging applied to microbial categorization in an automated microbiology workflow [9537-80]

953728 Non-contact high resolution Bessel beam probe for diagnostic imaging of cornea and trabecular meshwork region in eye [9537-82]

9537 2A Blood optical properties at various glucose level values in THz frequency range [9537-85]

9537 2B Cartilage analysis by reflection spectroscopy [9537-86]

9537 2C Energy transfer efficiency in quantum dot/chlorin e6 complexes [9537-87]

9537 2E Quantum dot-tetrapyrrole complexes as photodynamic therapy agents [9537-89]

$95372 \mathrm{H} \quad$ Combined autofluorescence and Raman spectroscopy method for skin tumor detection in visible and near infrared regions [9537-92]

95372 Paper-based surfaced enhanced Raman spectroscopy for drug level testing with tear fluid [9537-93] 


\title{
Authors
}

Numbers in the index correspond to the last two digits of the six-digit citation identifier (CID) article numbering system used in Proceedings of SPIE. The first four digits reflect the volume number. Base 36 numbering is employed for the last two digits and indicates the order of articles within the volume. Numbers start with 00, 01, 02, 03, 04, 05, 06, 07, 08, 09, OA, OB...0Z, followed by 10-12, 20-2Z, etc.

\author{
Abdat, F., OF \\ Abeygunawardhana, Pradeep K. W., 14, 15 \\ Amouroux, M., OF \\ Anand, Suresh, Ol, 1R \\ Arifler, Dizem, OM \\ Artemyev, D. N., $2 \mathrm{H}$ \\ Artyushenko, V., 20 \\ Arya, Shobhit, 17 \\ Atkins, Chad G., OX \\ Awazu, Kunio, 1C \\ Babar, H., IT \\ Baranov, Alexander V., 2C, 2E \\ Baria, Enrico, $1 \mathrm{R}$ \\ Bashkatov, A. N., 1P \\ Baskaran, M., 28 \\ Batista, Ana, 09 \\ Belousov, Vsevolod, 10 \\ Berlien, H.-P., 20 \\ Bernatova, Silvie, 03 \\ Beuf, Olivier, OL \\ Bjorgan, Asgeir, 0C, 12 \\ Blades, Michael W., OX \\ Blondel, W., OF \\ Bogomolov, A., 20 \\ Borovkova, M. A., 2A \\ Braglia, A., OS \\ Brandstetter, M., 13 \\ Braschi, G., OS \\ Bratchenko, I. A., $2 \mathrm{H}$ \\ Brittenham, G. M., 06 \\ Brown, J. Quincy, OA, OK, OP \\ Bruns, Thomas, 16 \\ Buccoliero, Anna Maria, Ol \\ Bucharskaya, A. B., IP \\ Buckley, Kevin, OX \\ Bürmen, Miran, OR \\ Bykov, A. V., 24 \\ Canaple, Laurence, OL \\ Castejón, Olga Ciutad, 09 \\ Ceja-Fdez, Andrea, 1H \\ Cepeda-Pérez, E. I., $1 \mathrm{H}$ \\ Chen, Chi, 10 \\ Chen, Deborah, OX \\ Chidangil, Santhosh, OJ \\ Chiew, Geraldine Giap Ying, 1B \\ Chuang, Min-Jie, IQ \\ Cicchi, Riccardo, OI, IR \\ Cigada, A., OS \\ Clancy, Neil T., 17
}

\author{
Cosci, Alessandro, IR \\ Crisci, Alfonso, ol \\ De Giorgi, Vincenzo, OI, IR \\ de la Rosa, E., 1H \\ Devine, Dana V., OX \\ Dinten, Jean-Marc, $\mathrm{OE}$ \\ Dolotov, L. E., IP \\ Domingues, José Paulo, 09 \\ Dorez, Hugo, OL \\ Douplik, A., $1 \mathrm{~T}$ \\ Druzhkova, Irina, 10 \\ Du, Xiaofei, 17 \\ Dudenkova, Varvara, 10 \\ Duliu, Alexandru, 22 \\ Duraibabu, D. B., OS \\ Eichler, H., 20 \\ Elfer, Katherine N., OA, OK, OP \\ Elson, Daniel S., 17 \\ Fedorov, Anatoly V., 2C, 2E \\ Fujiwara, Masaru, 14 \\ Gaillard, Sophie, OL \\ Gallati, M., OS \\ Gardiazabal, José, 22 \\ Genin, V. D., 1P \\ Genina, E. A., 1P \\ Giordano, Flavio, Ol \\ Gnyba, M., OZ, IN \\ Gonzalez-Yebra, Ana Lilia, 1H \\ Gorin, D. A., IP \\ Goryacheva, I. YU., IP \\ Graefe, Susanna, 05 \\ Graf, A., 1J \\ Grafen, M., 13 \\ Guermeur, Y., OF \\ Guerrini, Renzo, Ol \\ Guillaud, Martial, OM \\ Gusev, S. I., 2A \\ Hanna, George B., 17 \\ Haronikova, Andrea, 03 \\ Heise, H. M., 13 \\ Hennig, G., 06 \\ Hessling, M., 1 J, 2B \\ Hidalgo, Alberto, $1 \mathrm{H}$ \\ Homann, C., 06 \\ Hosono, Satsuki, 15 \\ Hsiao, Yi-Hsien, 1Q \\ Hsieh, Hong-Po, 1Q \\ Hsu, Fang-Wei, $1 Q$ \\ Ihrig, D., 13
}


Imbaud, Pierre, 26

Inohara, Daichi, 15

Ishida, Akane, 15

Ishii, Katsunori, 1C

Ishimaru, Ichiro, 14, 15

Jędrzejewska-Szczerska, M., 0Z, $1 \mathrm{~N}$

Jeong, Hieyong, 2 l

Jesmond, Hong Xun Jie, 28

Jezek, Jan, 03

Jo, Na rae, IF

John, Pauline, 11

Josse, Gwendal, OE

K., Unnikrishnan $V_{\text {., }}$ OJ

Kakino, Satoko, $1 \mathrm{E}$

Kannadorai, Ravi Kumar, 1B

Kapsokalyvas, Dimitrios, IR

Karpienko, K., IN

Kartha, V. B., OJ

Khodzitsky, M. K., 2A

Khristoforova, Y. A., 2H

Kido, Michiko, 21

Kienle, Alwin, 18

Kimbrell, Hillary Z., OA, OP

Kochubey, V. I., 1P, 24

Koenig, Anne, OE

Konyukhova, J. G., 1P, 24

Kozintseva, M. D., 1P

Kozlov, S. V., $2 \mathrm{H}$

Krause, H., 20

Kuehn, A., $1 \mathrm{~J}$

Kuznetsova, Vera, 2E

Lacey, Michelle, OP

Lang, A., 06

Larsson, Marcus, OC

Lasser, Tobias, 22

Laun, T., 2B

Le Digabel, Jimmy, OE

Lee, Benjamin R., OP

Lee, Ki joong, $1 \mathrm{~F}$

Leen, G., OS

Lendl, B., 13

Leonhardt, S., 13

Leroux, Denis F., 26

Lewis, E., OS

$\mathrm{Li}, \mathrm{An}, 10$

Likar, Boštjan, OR

Lilge, L., IT

Liu, Quan, 1B

LiU, Y., OS

Lomova, M., IP

López-Luke, T., 1H

Loschenov, Victor, 05

Lukina, Maria, 10

Lukyanov, Sergey, 10

Luo, Kathy Qian, 1B

Macchi, E. G., OS

Maio, Vincenza, OI, IR

Mandava, Sree, OP

Manoj, Murali, 11

Mantz, H., $1 \mathrm{~J}$
Martynenko, Irina V., 2C, 2E

Maslov, Vladimir G., 2C, 2E

Massi, Daniela, OI, IR

Matsui, Daichi, 1C

Matsuura, Yuji, 1E

Midahuen, Rony, 26

Milanic, Matija, OC

Milewska, D., iN

Miller, Christopher, OK

Miller, R., $1 \mathrm{~J}$

Minet, O., 20

Mlynarikova, Katarina, 03

Morgado, Miguel, 09

Moryatov, A. A., $2 \mathrm{H}$

Moser, $\mathrm{H}_{\text {., }} 13$

Moussata, Driffa, OL

Muenzer, M., 2B

Müller, Dennis, 18

Murukeshan, V. M., 28

Myakinin, $\mathrm{O}$. O., $2 \mathrm{H}$

Myllylä, T. S., $0 Z$

Nacy, L., $1 \mathrm{~T}$

Naglič, Peter, OR

Nalpantidis, K., 13

Navab, Nassir, 22

Navolokin, N. A., 1P

Nesi, Gabriella, 0 I

Nishiyama, Akira, 14, 15

Nogo, Kosuke, 15

Nothelfer, Steffen, 18

Obruca, Stanislav, 03

Ohno, Yuko, 2l

Ongole, Ravikiran, 0J

Orlova, Anna O., 2C, $2 \mathrm{E}$

Ostendorf, A., 13

Pai, Keerthilatha M., OJ

Pandya, A., IT

Patil, Ajeetkumar, 0J

Pavone, Francesco Saverio, Ol, $1 \mathrm{R}$

Pérez-Mayen, L., 1H

Pernuš, Franjo, OR

Perrin, Guillaume, 26

Perrone, G., OS

Pescatore, Jeremie, 26

Pieszczek, Ł., 20

Pimpinelli, Nicola, OI, IR

Poeggel, S., OS

Popov, A. P., 1P, 24

Princz, S., 1J, 2B

Quadrado, Maria João, 09

Randeberg, Lise Lyngsnes, 0C, 12

Rao, Suresh R., 11

Richter, Verena, 16

Roig, Blandine, $\mathrm{OE}$

Rossari, Susanna, OI, IR

Ryabova, Anastasia, 05

Sablong, Raphaël, OL

Saeb Gilani, T., 20

Saiko, G., $1 T$

Saint-Jalmes, Hervé, OL 
Samek, Ota, 03

Sasazawa, Shuhei, 1E

Sato, Shun, 14, 15

Scalfi-Happ, Claudia, 05

Schelkanova, I., IT

Schickinger, Sarah, 16

Schlichenmeyer, Tyler C., OP

Schneckenburger, Herbert, 16

Schulte, F., 20

Schulze, H. Georg, OX

Sergeeva, Tatiyana, 10

Shah, D., IT

Shen, Junfei, 10

Shin, Yong-Beom, IF

Shinoj, V. K., 28

Shirmanova, Marina, 10

Sholl, Andrew B., OA, OK, OP

Siler, Martin, 03

Silva, Susana F., 09

Skaptsov, A. A., 24

Speranskaya, E., IP

Stark, Julian, 18

Steiner, Rudolf, 05

Stepp, H., 06

Stoyanov, Danail, 17

Strepitov, M. A., 2A

Strömberg, Tomas, OC

Sujatha, N., 11

Sukhorukov, G. B., IP

Sung, Kung-Bin, 1Q

Suzuki, Satoru, 14, 15

Suzuki, Yo, 15

Terentyuk, G.S., IP

Tien, Gen-Hao, 1Q

Tin, Aung, 28

Torres-Castro, Alejandro, $1 \mathrm{H}$

Tosi, D., OS

Tuchin, V. V., 1P, 24

Tulman, David B., OA, OP

Turner, Robin F. B., OX

Urniaż, R., $0 Z$

Usenov, I., 20

Vahlsing, T., 13

Vallan, A., OS

Vasa, Nilesh J., 11

Visheratina, Anastasia K., 2C, 2E

Vivero-Escoto, Juan, $1 \mathrm{H}$

Vogeser, M., 06

Volkova, E. K., 1P, 24

Wada, Kenji, 14, 15

Wagner, Michael, 16

Wang, Huihui, 10

Wang, Mei, OA, OP

Weber, Petra, 16

Wenzel, U., 1J, 2B

Wittig, Rainer, 05

Wróbel, M. S., OZ, $1 \mathrm{~N}$

Wu, Yisi, 10

Yamada, Kenji, 2

Yanina, I. YU., 1P, 24
Yokoyama, Moe, 21

Zabarylo, U., 20

Zagaynova, Elena, 10

Zakharov, V. P., $2 \mathrm{H}$

Zemanek, Pavel, 03

Zheng, Zhenrong, 10 
Proc. of SPIE-OSA Vol. $9537953701-10$

Downloaded From: https://www.spiedigitallibrary.org/conference-proceedings-of-spie on 25 Apr 2023 Terms of Use: https://www.spiedigitallibrary.org/terms-of-use 


\title{
Conference Committee
}

\author{
General Chairs \\ Andreas Hielscher, Columbia University (United States) \\ Jürgen Popp, Friedrich-Schiller Universität Jena (Germany) \\ Programme Chairs \\ Rainer Leitgeb, Medizinische Universität Wien (Austria) \\ Nirmala Ramanujam, Duke University (United States) \\ Conference Chairs \\ J. Quincy Brown, Tulane University (United States) \\ Volker Deckert, Institut für Photonische Technologien e.V. (Germany) \\ Conference Programme Committee \\ Yu Chen, University of Maryland, College Park (United States) \\ Darren M. Roblyer, Boston University (United States) \\ Kristen C. Maitland, Texas A\&M University (United States) \\ Melissa C. Skala, Vanderbilt University (United States) \\ Jonathan T. C. Liu, University of Washington (United States) \\ Quan Liu, Nanyang Technological University (Singapore) \\ Niels Bendsoe, Lund University Hospital (Sweden) \\ Thomas G. Mayerhöfer, Institut für Photonische Technologien e.V. \\ (Germany) \\ Lise Lyngsnes Randeberg, Norwegian University of Science and \\ Technology (Norway) \\ Kishan Dholakia, University of St. Andrews (United Kingdom) \\ Alastair J. M. Watson, Royal Liverpool and Broadgreen University \\ Hospitals NHS Trust (United Kingdom) \\ Francesco Pavone, European Laboratory for Non-linear \\ Spectroscopy (Italy) \\ James W. Tunnell, The University of Texas at Austin (United States) \\ Session Chairs \\ 1 Biospectroscopy and POC Diagnostics \\ J. Quincy Brown, Tulane University (United States) \\ 2 Clinical and Preclinical Diagnostics I \\ J. Quincy Brown, Tulane University (United States)
}


3 Clinical and Preclinical Diagnostics II

Lise Lyngsnes Randeberg, Norwegian University of Science and Technology (Norway)

4 Clinical and Preclinical Tissue Characterization I

Pilar Beatriz García-Allende, Technische Universität München (Germany)

5 Clinical and Preclinical Tissue Characterization II Riccardo Cicchi, Istituto Nazionale di Ottica (Italy)

6 Minimally Invasive Diagnostics / Laboratory Medicine I J. Quincy Brown, Tulane University (United States)

$7 \quad$ Minimally Invasive Diagnostics / Laboratory Medicine II Quan Liu, Nanyang Technological University (Singapore)

8 Novel Techniques in Diagnosis, Therapy, and Monitoring Herbert Schneckenburger, Hochschule Aalen (Germany)

ECBO Post-Deadline Session

Rainer Leitgeb, Medizinische Universität Wien (Austria) 


\section{Introduction}

These proceedings are from Clinical and Biomedical Spectroscopy and Imaging IV, held June 22-24, 2015 at the European Conferences on Biomedical Optics in Munich, Germany. This year's conference comprised 45 oral and 42 poster presentations from leading international research groups.

The conference was organized into five tracks and ten sessions including: Biospectroscopy and POC Diagnostics; Clinical and Preclinical Diagnostics I and II; Clinical and Preclinical Tissue Characterization I and II; Minimally Invasive Diagnostics / Laboratory Medicine I and II; and Novel Techniques in Diagnosis, Therapy, and Monitoring. A poster session and corresponding poster preview session were also held.

The Biospectroscopy and POC Diagnostics session contained six oral presentations, on topics ranging from label-free Raman analysis of microorganisms to fluorescence-based rapid porphyria diagnostic tests and multi-spectral surface plasmon resonance sensing.

The Clinical and Preclinical Diagnostics track covered two sessions containing 10 oral presentations. Reports included a number of ex vivo and in vivo clinical applications, including the use of targeted fluorescence guidance in gastrointestinal endoscopy, fluorescence lifetime imaging of corneal metabolism, rapid near-patient fluorescence microscopy of prostate biopsies, tracking of lipids and invasomes in stratum corneum using TERS, noninvasive detection of hypercholesterolemia using hyperspectral skin imaging, comprehensive analysis of in vivo skin optical properties and vascular parameters using diffuse reflectance spectroscopy, deep skin optical property extraction using diffuse reflectance spectroscopy, improved precancer diagnosis using fusion of autofluorescence and diffuse reflectance spectroscopy, the use of diffuse optics to probe the bone marrow for oncological management, and characterization of the thyroid using diffuse optics.

The Clinical and Preclinical Tissue Characterization track also covered two sessions with 11 oral presentations, and included reports on tissue diagnostics using a combined Raman and fluorescence fiber probe, early diagnosis of tongue malignancies using fluorescence spectroscopy, a fluorescent replacement for traditional H\&E histopathology, characterization of colitis using autofluorescence spectroscopy, analysis of length-scale variations on light scattering patterns of cells, the use of NIRS to monitor tumor microwave ablation, clinical results on the use of Raman spectroscopy to discriminate inflammatory bowel diseases, the use of structured illumination microscopy to image entire prostate surgical margins, an analysis of the effect of realistic fiber probe interfaces on Monte-Carlo simulated diffuse reflectance, fiber optic thermotherapy for liver tumors, and the effects of 
pressure on tissue optical properties measured by single-fiber reflectance spectroscopy.

The Minimally Invasive Diagnostics/Laboratory Medicine track covered two sessions with 12 oral presentations. Topics included lab-on-a-chip SERS for levofloxacin detection in body fluid, SERS for detection of harmful environmental substances, Raman spectroscopy of biogenic gases in hollow-core fibers, Raman spectroscopic temporal monitoring of the quality of stored whole donated blood, a novel method to create a universal calibration data set for Raman reconstruction based on Wiener estimation, detection of propofol in blood by Raman spectroscopy, intracellular pH sensing in cells using genetically encoded ratiometric sensors, measurement of aqueous glucose using differential absorption frequency domain OCT, real time medical diagnostics using hyperspectral imaging, spectroscopic characterization of an ultra-broadband tunable quantum cascade laser, spectroscopic imaging of blood glucose in superficial skin vessels, and a battery operated ATR Fourier spectrometer for in situ glucose monitoring.

The Novel Techniques in Diagnosis, Therapy, and Monitoring contained six oral presentations on 3D imaging of apoptosis using light sheet microscopy, reflectance property analysis of RF-fused bowel tissues, analysis of yeast cells using light scattering microscopy, the use of light scattering microscopy for probing apoptosis and tumor cell recognition, the use of 5-ALA for see-and-treat in Barrett's esophagus cellular models, and the use of gold nanorods to track cell death during plasmonic photothermal therapy.

The conference chairs very gratefully acknowledge the members of the programme committee for their work in peer reviewing and scoring the three-page summaries submitted to the conference. In addition, we are grateful to SPIE staff for their help and support during the organization of the conference. Finally, we would like to thank all of the conference attendees and authors for contributing to this year's successful conference. 